\title{
20 Years of the Croatian Capital Market
}

\author{
Mihaela Grubišić Šeba *
}

\begin{abstract}
From 1990s to the end of 2006 there have been two stock exchanges in Croatia - an official stock exchange in Zagreb and a so-called alternative capital market in Varaždin. The Zagreb stock exchange had a dominant role in the Western Balkan region until 2008, when its market capitalisation significantly decreased because of the influence of the global financial crisis and the economic downturn of the country. This paper analyses gradual regulatory and institutional development of the Croatian capital market, emergence and strengthening of institutional investors and assets under their management, key market development indicators related to market supply and demand and investor protection mechanisms. The research presented in this paper has shown the crucial role of regulation in attracting investors and sustaining their presence in the market. It also recommends more active role of regulation and stock exchange towards the issuers and small investors to encourage constant supply of corporate securities.
\end{abstract}

Keywords: capital market, regulation, corporate governance, investor protection, Croatia

JEL Classification: G38, G23

\section{Introduction}

Croatian capital market shares many common features with emerging capital markets in general and with transition capital markets in particular. On one side, Croatia has a typical bank-based financial system in which small entrepreneurs, without proven credit track-record, cannot finance their business operations at favourable interest rates. On the other side, the citizens hold excess savings in euro-denominated bank accounts and/or in money-market funds in spite of relatively low interest rates. An alternative to bank savings are rather illiquid real estate. Plenty of research investigated the importance of both bank-based and market-based financial systems. In a nutshell, legal sys-

\footnotetext{
* Mihaela Grubišić Šeba is an independent senior consultant and a senior research associate based in Zagreb, Croatia.
} 
tem matters (La Porta et al., 2000), both bank-based and market financial systems are important for economic development of the countries, whereby bank-based systems are more important for less developed economies. However, recessions are much deeper in bank-based systems than in market-based ones (Gambacorta et al., 2014).

All planned economies of the CEE and SEE started developing their capital markets on privatisation waves of state-owned enterprises in 1990s. The privatisation models differed and the privatisation impacts on capital market developments have ranged from rather short-term to mid-term (Kogut and Spicer, 2002).

The development of the Croatian capital market has been marked by the regulation and institutional investors' presence. During 1990s the privatisation caused market turnover has been mostly bound to the OTC market, which existed parallel with the official stock exchange in the city of Varaždin. There have been about 70 listed securities on Zagreb stock exchange at the end of 2001. The specificity of the Croatian capital market is that demand for securities was created before supply at the beginning of the third millennium. Apart from banks, insurance companies, brokerages and investment funds, the pension reform created a new group of institutional investors that needed to regularly invest funds into securities - mandatory and voluntary pension funds. Although the regulation prevented pension funds from being prone to risk, the supply of liquid corporate securities has been scarce and relied on three stock issues listed in the first quotation, i.e. the pharmaceutical company Pliva, the food manufacturer Podravka, and the shipyard Viktor Lenac. The liquidity of other stocks rested with largest banks shares and some shares of tourist companies. As a result, the mandatory shares listing rule ordered the companies with more than 100 shareholders or with more than 30 million kuna shareholders capital to list their shares on the stock exchange by mid-2003. The mandatory share listing rule temporarily hide the ownership concentration problem that arose as a direct consequence of dispersed ownership in 1990s and inability of minority shareholders to exercise their ownership rights (OECD, 2003). The literature on Croatian capital market development has been developed into several directions - government debt market development (Štimac, 2011), coporate debt issuance (Miloš Sprčić and Wilson, 2007), market (i)lliquidity and underdevelopment (Benić and Franić, 2008; Minović, 2012; Buljat et al., 2015), taxation policy (Orsag, 2011), market valuation (Anić Antić and Ramljak, 2010; Sajter and Čorić, 2009), financing policies of listed companies (Grubišić Šeba, 2013; Grubišić Šeba and Orsag, 2015), legal rules affecting corporate market activities and minority shareholder rights (Čulinović Herc, 2009; Čulinović Herc and Zubović, 2013). The list of research is hereby not exhaustive. This paper analyses various aspects of the Croatian capital market development within its historical context, in particular the role of regulation and policy in creation of an investor-friendly platform as an alternative for bank financing of the SME sector. By means of historical data obtained from publicly available resources (Zagreb stock exchange, Central depository and clearing company, Croatian financial services supervisory agency and Ministry of Finance), this paper aims to confirm or reject the following three hypotheses: 
H1. The market serves for government debt issuance purposes

$\mathrm{H} 2$. The market serves listed companies for advertising purposes

H3. Regulation and policy failed to spur small investor activity on the market.

The hypotheses testing is embedded throughout the paper which chronologically follows Croatian capital market development. The paper is organised in six sections. After the introductory part, the second section is devoted to regulatory framework development. The third and fourth section analyse market demand and supply, respectively. Fifth part of the paper discusses corporate governance principles, while the last section concludes.

\section{Regulatory Framework}

The regulatory framework of the capital market has been intertwined with the company and accounting laws, capital market regulation, stock exchange admission to trading and listing rules, and a number of by-laws. The regulatory path of the Croatian capital market can be divided into two phases - the first phase has been a transitory phase from the planned to the market-based economy, while the second phase is characterised by the adjustment of domestic regulatory framework to the European acquis. The transitory phase lasted from the 1990s to the end of 2008, and it can be divided in two sub-periods. In the first sub-period the package of laws brought in before the break-down of the former Yugoslavia was in force. It was superseded by Croatian laws in mid-1990s which established the Croatian Depository Agency and the market regulator - then Securities and Exchange Commission. The latter was renamed to the Croatian Financial Services Supervisory Agency in 2008, when its scope of activities has been broadened to monitoring the capital market and its supporting institutions, monitoring insurance companies, leasing and factoring companies, investment firms (brokerages), investment and pension funds and their managing companies, and overseeing the takeover processes of the joint-stock companies. A set of capital market laws encompasses:

- Act on Issuance and Sale of Securities (later Securities Market Act, and thereafter Capital Market Act)

- laws regulating institutional investors' presence such as Law on Investment Funds and Law on Mandatory and Voluntary Pension Funds, laws regulating operations of insurance companies, foreign investors, privatisation investment funds

- laws regulating the supporting institutions on the market such as Central depository and clearing company, the stock exchange, and supervisory agency

- a set of by-laws prescribing maximum allowed percentage of institutional investors' assets invested into certain types of financial instruments and/or certain types of issuers. 
The key regulatory advances are presented in table 1. Only the core regulation that reflects capital market development and the behavior of its actors is presented, while some laws and by-laws have been excluded for the purpose of clarity. Dark grey color denotes the regulation on investor protection, grey depicts the regulation on capital market and its supporting institutions, while light grey marks the laws on certain institutional investors.

Table 1: Key regulatory developments of the Croatian capital market from 1990s2015

\begin{tabular}{|c|c|c|}
\hline $\begin{array}{c}\text { Month/year } \\
\text { of application }\end{array}$ & Regulation name (source) & Major novelties \\
\hline 06/1993 & $\begin{array}{l}\text { Law on foundations } \\
\text { of FX system, FX and } \\
\text { gold transactions (COG } \\
\text { 91a/1993) }\end{array}$ & $\begin{array}{l}\text { - Allows international investors to buy and sell domestic securi- } \\
\text { ties }\end{array}$ \\
\hline $10 / 1993$ & $\begin{array}{l}\text { Law on banks and saving } \\
\text { banks (COG 94/1993) }\end{array}$ & $\begin{array}{l}\text { - Banks are the first institutional investors allowed to buy and } \\
\text { sell securities }\end{array}$ \\
\hline $12 / 1995$ & $\begin{array}{l}\text { Law on investment funds } \\
\text { (COG 107/1995) }\end{array}$ & $\begin{array}{l}\text { - Regulates the foundation and activities of the closed-end, open- } \\
\text { end and real-estate investment funds; } \\
\text { - Differs between legal entities that manage the funds, assets } \\
\text { managed in the funds, and depositary banks } \\
\text { - Prescribes the limits for investments into certain asset classes }\end{array}$ \\
\hline $01 / 1996$ & $\begin{array}{l}\text { Act on issuance and sale of } \\
\text { securities (COG 107/1995) }\end{array}$ & $\begin{array}{l}\text { - Securities and Exchange Commission was established } \\
\text { - prescribes rights and obligations of the Stock exchange and in- } \\
\text { vestment companies } \\
\text { - regulates IPOs and listing of domestic and foreign securities } \\
\text { and mandatory content of prospectus } \\
\text { - contains market abuse prevention and investor protection rules }\end{array}$ \\
\hline $10 / 1997$ & $\begin{array}{l}\text { Law on privatisation } \\
\text { investment funds (COG } \\
\text { 109/1997) }\end{array}$ & $\begin{array}{l}\text { - regulates transfer of privatisation coupons collected by the } \\
\text { fund into corporate shares }\end{array}$ \\
\hline $10 / 1998$ & $\begin{array}{l}\text { Amendment of the Act } \\
\text { on issuance and sale of } \\
\text { securities (COG 142/1998) }\end{array}$ & $\begin{array}{l}\text { - Croatian Depository Agency was established } \\
\text { - Determines a maximum 6-month period for subscription of } \\
\text { publicly offered securities and a maximum 3-month period for } \\
\text { subscription of privately offered securities } \\
\text { - Public offering of securities is successful if } 80 \% \text { of the offered } \\
\text { securities are subscribed by investors }\end{array}$ \\
\hline $\begin{array}{l}05 / 1999 \text { and } \\
\text { partly in } \\
01 / 2000\end{array}$ & $\begin{array}{l}\text { Law on mandatory and } \\
\text { voluntary pension funds } \\
(\text { COG 49/1999) }\end{array}$ & $\begin{array}{l}\text { - Introduces mandatory and voluntary pension funds and pen- } \\
\text { sion companies in the market }\end{array}$ \\
\hline $07 / 2002$ & $\begin{array}{l}\text { Securities Market Act } \\
\text { (COG 184/2002) }\end{array}$ & $\begin{array}{l}\text { - Prescribes mandatory shares listing rule for the joint stock } \\
\text { companies with at least } 30 \text { million kuna of shareholders capital } \\
\text { and/or } 100 \text { shareholders, and for joint stock companies engag- } \\
\text { ing into initial public offering of their shares } \\
\text { - All listed companies had to issue prospectus with most relevant } \\
\text { information for investment decision }\end{array}$ \\
\hline $07 / 2002$ & $\begin{array}{l}\text { Takeover Act } \\
(\text { COG No. 84/2002) }\end{array}$ & $\begin{array}{l}\text { - Prescribes the takeover rules for joint stock companies } \\
\text { - Determines the lowest takeover price in subsequent takeover bids }\end{array}$ \\
\hline
\end{tabular}




\begin{tabular}{|c|c|c|}
\hline $\begin{array}{c}\text { Month/year } \\
\text { of application }\end{array}$ & Regulation name (source) & Major novelties \\
\hline $06 / 2003$ & $\begin{array}{l}\text { Law on foreign exchange } \\
\text { transactions (COG } \\
96 / 2003 \text { ) }\end{array}$ & $\begin{array}{l}\text { - Regulates issuance of domestic (foreign) securities in the inter- } \\
\text { national (domestic) capital market } \\
\text { - Regulates cash flows arising from the holdings in securities be- } \\
\text { tween residents and non-residents }\end{array}$ \\
\hline $01 / 2004$ & $\begin{array}{l}\text { Amendment of the } \\
\text { Company Act (COG } \\
118 / 2003)\end{array}$ & $\begin{array}{l}\text { - Introduces annual statement on (dis)obeying corporate gover- } \\
\text { nance rules for management and supervisory boards of publicly } \\
\text { listed companies }\end{array}$ \\
\hline $01 / 2006$ & $\begin{array}{l}\text { New Law on investment } \\
\text { funds (COG 150/2005) }\end{array}$ & - Introduces venture capital funds \\
\hline $12 / 2006$ & $\begin{array}{l}\text { Securities Market Act } \\
\text { amendment (COG } \\
138 / 2006)\end{array}$ & $\begin{array}{l}\text { - Increases the shareholders' capital of the stock exchange from } \\
1-20 \text { million kuna; }\end{array}$ \\
\hline 2007 & Corporate governance code & - It is voluntary and it is issued by the Zagreb stock exchange \\
\hline $10 / 2007$ & $\begin{array}{l}\text { Takeover Act (COG No. } \\
\text { 109/2007) }\end{array}$ & $\begin{array}{l}\text { - The takeover price cannot be lower than the price paid for the } \\
\text { shares of target company in the period of one year preceding } \\
\text { the takeover bid } \\
\text { - If } 95 \% \text { of shares are taken over, the acquirer can purchase the } \\
\text { rest within three months from the takeover process closure. } \\
\text { Equally, the minority shareholders can in the same period sell } \\
\text { their shares to the acquirer. }\end{array}$ \\
\hline $01 / 2009$ & Capital Market Act & $\begin{array}{l}\text { - Adjusts Croatian regulatory framework with the EU acquis by } \\
\text { the adoption of the Lamfaloussy directives } \\
\text { - Differs between small and institutional investors } \\
\text { - The market platform has been divided into Regulated market } \\
\text { and Multilateral trading platform, i.e. alternative market } \\
\text { - Introduces market making } \\
\text { - Abolishes mandatory listing rule } \\
\text { - Introduces derivatives and structured products trading } \\
\text { - Increases the shareholders' capital of Zagreb stock exchange to } \\
40 \text { million kuna } \\
\text { - Introduces the Investors Protection fund } \\
\text { - Listed companies have stricter disclosure rules } \\
\text { - The form for financial statements disclosure has been changed } \\
\text { - Introduces investor protection fund }\end{array}$ \\
\hline $05 / 2010$ & $\begin{array}{l}\text { Company Act amendment } \\
(\text { COG 137/2009) }\end{array}$ & $\begin{array}{l}\text { - Corporate governance statement by management and supervi- } \\
\text { sory boards becomes an integral part of the annual report of } \\
\text { publicly listed companies }\end{array}$ \\
\hline 2010 & $\begin{array}{l}\text { Revised Corporate } \\
\text { Governance Code }\end{array}$ & $\begin{array}{l}\text { - Publicly listed companies need to fill in and disclose annual } \\
\text { corporate governance questionnaire with } 68 \text { main questions on } \\
\text { corporate governance practice until the end of June for the pre- } \\
\text { vious year }\end{array}$ \\
\hline $12 / 2013$ & $\begin{array}{l}\text { Takeover Act Amendment } \\
\text { (COG No. 148/2013) }\end{array}$ & $\begin{array}{l}\text { - The price on the stock market prevails, meaning that the bidder } \\
\text { is obliged to offer average market price in the period of three } \\
\text { months prior to the takeover bid, except when trading was not } \\
\text { held in less than } 1 / 3 \text { of trading days in the specified period }\end{array}$ \\
\hline
\end{tabular}

Source: Author's selection. Full texts of the laws can be found on Croatian Official Gazette (COG) internet site: http://narodne-novine.nn.hr/default.aspx, in Croatian. Only the latest text on corporate governance code is available on Zagreb stock exchange Internet site: www.zse.hr 
As it is evident from the data presented in Table 1, the first institutional investors in the Croatian capital market have been banks, followed by the investment funds and privatisation investment funds. The largest institutional investors - pension funds have been created as a support to the pension reform in 2000 , but they become operational in 2001. Until the modern Capital Market Act, the regulation on securities market and institutions had been in force since 1996, with a few changes. Mid-2002 is regarded as the year of introducing first mandatory corporate governance principles by prescribing quarterly financial reports disclosure to majority of publicly listed companies.

\section{Market Demand}

In mid-1990s there have been about 600.000 small investors in shares, i.e. every fifth citizen owned shares, mostly owing to preceding coupon privatisation. But, as a result of shares consolidation ownership in many companies become concentrated in hands of one or several natural persons, and/or legal entities. Following the partial privatisations of telecom and oil and gas company the number of small investors increased again during 2006 and 2007 but it has been gradually decreasing ever since. Foreigners' ownership in corporate shares mostly arises from the purchase of the state-owned stakes in the largest banks, telecom, and some manufacturing companies by early 2000s. The statistics by investor type in shares and overall investments in debt securities is shown in figure 1. Bond and commercial paper investors are domestic legal entities and portfolio investors. The share of debt securities in overall market value increased from 16\% in 2006 to about 29\% from 2013-2015. The rest of market value up to the total market value of $100 \%$ accounts mostly to shareholders. Foreign capital in domestic corporate shares increased in 2006 due to the takeover of the largest domestic pharmaceutical company Pliva. Likewise, the number of domestic small investors and custody/portfolio investors temporarily increased in 2006 and 2007 due to partial privatisations by initial public offer of national oil and gas and telecom shares, respectively. While the share of domestic small investors slightly decreased from $14 \%$ in 2007 to $10 \%$ in 2013, when it suddenly increased due to takeover activity, the share of custody and portfolio accounts melted down from $21 \%$ in 2007 to about $3 \%$ in 2009, the level that stood almost the same until the beginning of 2016. Corporate short term debt, i.e. commercial papers (CPs), that are commonly issued in several tranches, have dominated corporate debt market. CPs have even more often been issued by issuers in private as an alternative to short-term bank loans, probably due to relatively small lower bound of the issue of 8 million kuna and a revolving issuance possibility given by the CP issuance programme valid typically up to three or five years . Figure 1 needs to be compared with figure 2 that shows historical market activity of the Croatian capital market. Regular stock 
turnover that includes block transactions has been dominant on the Zagreb stock exchange compared to regular bond turnover. The OTC turnover in shares has been significant on the Varaždin stock exchange from the application of the mandatory shares listing rule in 2002 until the closure of the market. Unlike constant increase in market capitalisation of listed domestic bonds, dominantly government bonds, from $15 \%$ in 2001 over $10,6 \%$ in 2007 to $38 \%$ in 2015 , the market capitalisation of stocks has been constantly reduced from $100 \%$ in the period $1996-2000$ to $61 \%$ of overall market capitalisation at the end of 2015. Stock market capitalisation corresponds to the CROBEX index value, the barometer of the stock market activity that has been calculated and periodically reviewed from 1997 thereon. Market capitalisation of shares has been prevailing in overall market capitalisation. However, the market turnover has been much higher in bonds. Regular bond turnover on the ZSE includes block trades greater than 3 million kuna, but it still lags significantly behind the institutional (OTC) turnover. Market turnover values warn on primary activity in government debt securities, while corporate securities, although much higher in market capitalisation, are typically closely held and not traded. This supports the first research hypothesis that the market serves mainly for government debt issuance and trading purposes.

Figure 1: Investors in domestic shares and other securities according to their market value, 2006-2015

Investors by type in domestic shares according to their market value, in million kuna (\%), 2006-2015

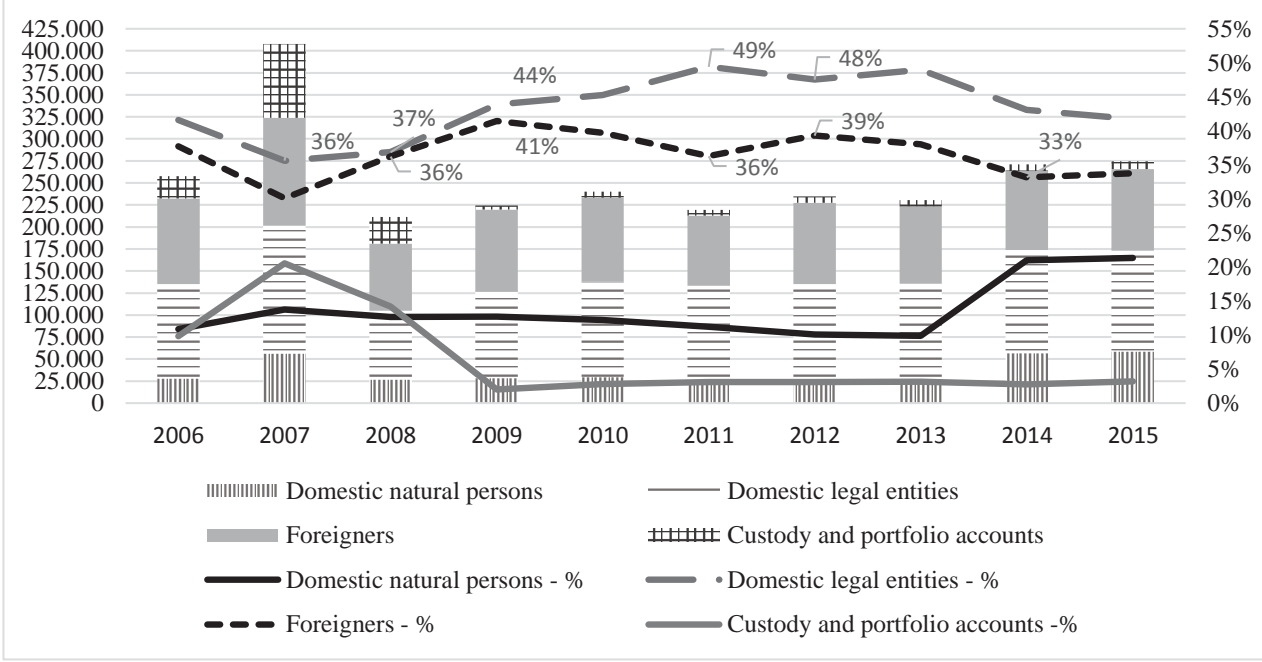

Source: Illustrated from the data of the Central Depository and Clearing Company 
Figure 2: Total turnover and market capitalization of the Croatian capital market, 1996-2015, in million kuna

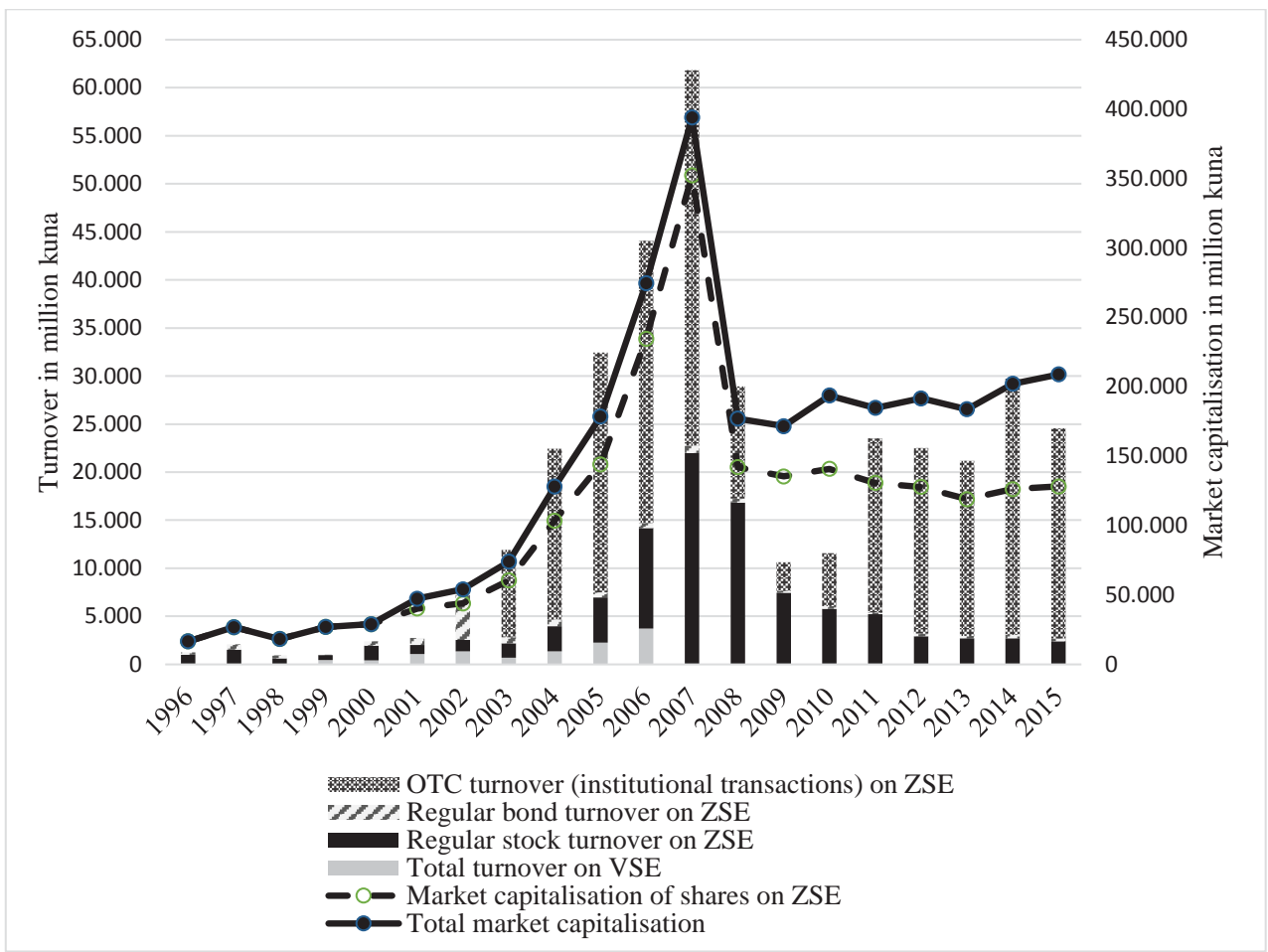

Source: Data obtained from the Zagreb stock exchange statistical reports

Major interest in domestic shares and bonds is provoked by the domestic institutional investors, i.e. institutional investors registered in Croatia. Due to favourable interest rates, corporate debt securities have been mostly subscribed by the institutional investors and held until their maturity. As evidenced from figure 4, most cash flows arising from securities holdings are bound to the interest/principal repayments, while dividends represent a small portion of the cash flows. However, the receivers of dividends significantly outnumber the receivers of cash flows arising from debt securities, especially following partial privatisations of state holdings between 2006 and 2007, suggesting the primary role of institutional investors in debt market. Owing to the pension reform, the pension funds have been receiving stable monthly cash inflows that made their assets grow from 2 to 74 billion kuna from 2002 to 2015. Most of their assets has been invested in domestic government bonds.

Significant portion of overall capital market capitalisation and turnover has been owed to government bonds. Apart from government bonds denominated in foreign currencies and issued in the foreign markets, two types of bonds have been issued in 
the domestic capital market. These are marketable government bonds and non-marketable bonds issued for the purpose of big system restructurings. Until 2003, government bonds were only dual currency bonds, i.e. bonds denominated in euro but payable in kuna at the Central Bank's fixing rate (Prohaska and Olgić Draženović, 2010).

The assets of open-end and closed-end investment funds increased at a much slower pace, from over 1 billion kuna in 2002 to over 15 billion kuna in 2015. As shown on figure 3, most institutional investors' assets, especially those of mandatory pension funds, have been invested in domestic government bonds and held until maturity. This fact is also evident from the interest/principal cash flows illustrated on figure 4 . The second investment priority has been given to money-market instruments as the most represented investment funds/UCITs by assets. In bank-based financial

Figure 3: Investments of UCITs and pension funds in domestic and foreign financial instruments, in million kuna, 2002-2015

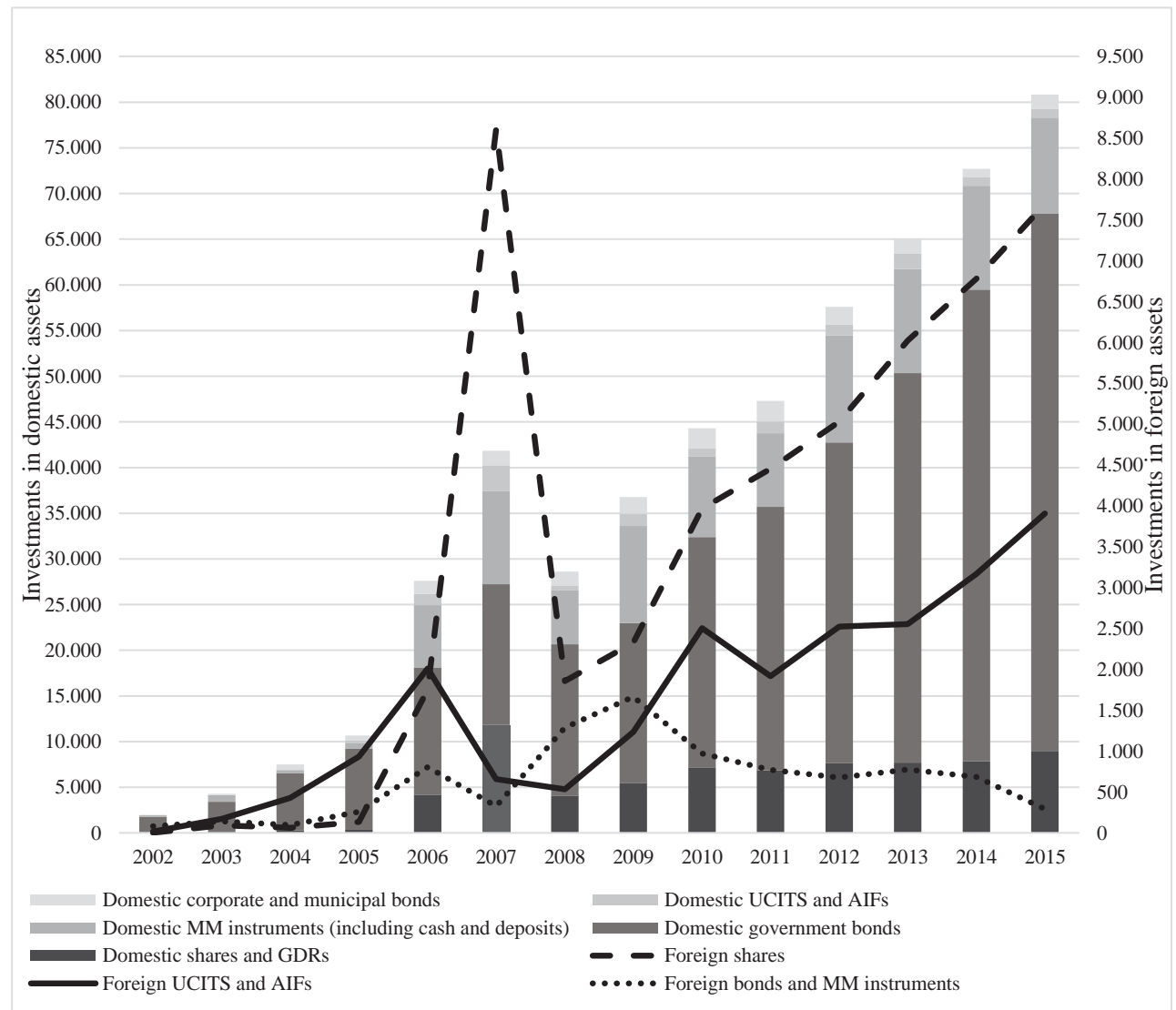

Source: Illustrated from the HANFA statistical database 
systems most savings are in the form of bank deposits. Hence, it is logical that investors changed bank savings for liquid money-market instruments. Money-market investment funds had 46\% stake in total investment funds' assets in 2002 and $60 \%$ stake in total funds' assets in 2015. Domestic shares are the third most important investment class in institutional investor portfolios. After the slump of stock markets in 2008 , investments in both domestic and international shares have been on increase. While domestic shares represented $97 \%$ of total investments in shares by investment and pension funds in 2002, this stake was 58\% in 2007 and 54\% in 2015, whereby mandatory pension funds as long term investors have been most active in supporting domestic stock market.

Figure 4: Cash flows in the Croatian capital market and the number of investors receiving cash, 2005-2015

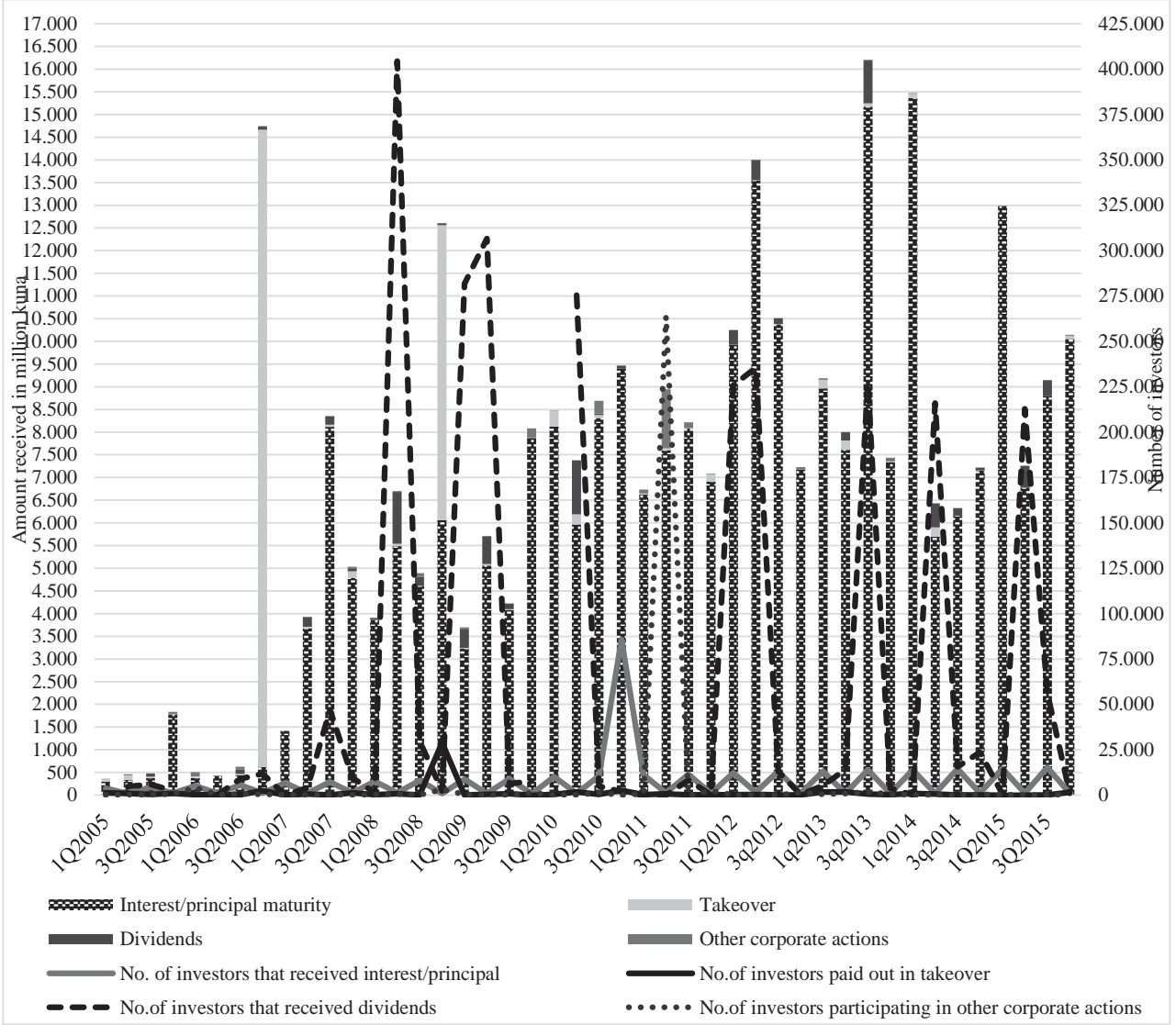

Source: Illustrated from the Central Depository and Clearing Company database 
Domestic securities listings in the international market have been rare. Only Pliva and Podravka had international listings in the form of global depository receipts (GDRs or commercial papers) in London before 2000. Partial privatisations of state stakes in oil and gas company INA and Croatian telecom resulted in GDRs listing in London. However, due to small liquidity and major interest of domestic institutional investors only, both companies' GDRs have been delisted from the London stock exchange and their GDRs have been replaced by the common shares in the domestic market during 2014.

\section{Market Supply}

All shares listed on the regulated market or on the multilateral trading platform as of 2009 (earlier on the alternative or parallel market) that are available for trading on a daily basis represent market supply. One of qualifying criteria for stocks listing into certain market quotation is expected liquidity of the stocks, i.e. the amount or percentage of a stock issue that can be freely traded on the market (free float). Unlike the companies that mandatorily listed their shares on the market, the companies that voluntary list their shares are typically very careful of the stock liquidity due to boosting its reputation, signalling transparency to investors and business partners, and possibly reducing its financing costs. The rise of stock turnover corresponds with market index rise and the only time of significant corporate shares IPOs in 2006 and 2007 (figure 5). A sudden explosion of the number of listed shares at the time is a consequence of the merger of two stock exchanges. The number of listed shares relies on the regulated market only and it has been constantly reduced due to the strict listing obligations of the issuers valid from 2009 thereon. Both the average daily turnover and the average daily number of transactions follow the market index movements. At CROBEX peak in 2007, average daily stock turnover reached about 270 million kuna, while the average daily number of transactions had its maximum in 2008 at 3045. An average value traded per transaction was about 108 thousand kuna in 1997, over 450 thousand kuna in 2004, 128 thousand kuna in 2007 to fall to less than 20 thousand kuna in 2011-2015 period. It warns on the activity of mostly institutional investors until the IPOs, while the smaller transactions in the last few years suggest very low shares valuations and further ownership concentration and corporate purchase of own shares with overall goal of their delisting from the market. Recession in the real sector of economy accompanied with the influence of the global financial crisis has had a big impact on the capital market development from 2008-2015. Even though the market indices of developed companies whose banks had been hit by the financial crisis have fully recovered in this period, CROBEX has been stagnating in line with other Western Balkan countries' stock indices. Daily movements of the market index have been correlated to American stock indices after the onset of the 
financial crisis despite weak economic relations between Croatia and the USA and with far less effect on domestic market (Sajter and Čorić, 2009). The latter suggested slight corrections of portfolio value held by institutional investors only.

In spite of the mandatory listing rule, the number of joint stock companies in private has outnumbered the number of listed joint stock companies suggesting that most joint stock companies has had shareholder capital lower than 30 million kuna and suggesting that there have not been many large domestic companies. The number of total joint stock companies fell from 939 in 2005 to 886 in 2015 in the registry of Central Depository and Clearing Company, as a result of a gradual takeover/merger or bankruptcy trend. Shares turnover as a percentage of shares market capitalisation reveals small shares liquidity, while overall securities turnover as a percentage of total securities market capitalisation suggests overwhelming debt securities trading and majority trading activity realised between the institutional investors.

Croatian capital market has dominantly been the market for ownership change and ownership concentration, i.e. a pure secondary financial market. Very few companies collected funds in IPOs or secondary shares offerings. Some IPOs that captured favourable market timing around state stakes divestitures during 2006 and 2007 were for exiting of private investors and not for fresh capital influx into the companies. However, big domestic companies have been quite often engaged into corporate debt securities offerings as an alternative to bank debt. The companies that had listed shares in the market have been more prone to commercial paper programme issuance, while privately-held companies engaged into corporate bonds issuance. Private offers of shares dominated, questioning the role of the market for primary financing purposes (Grubišić Šeba, 2015). Despite significant administrative burden to the listed companies and despite low liquidity and predominant role of the market for ownership change only and despite many delistings shown in figure 5, many companies choose to be listed for reputational reasons. The stock exchange listing serves as a relatively low (direct) cost advertising opportunity that occasionally attracts the attention of business press and stakeholders to the listed companies. It goes in support of the second hypothesis on advertising role of the market for corporate shares issuers. An earlier research also showed that greater transparency is not an obstacle to shares listing to majority of issuers (Grubišić Šeba, 2013).

Corporate debt activity was much stronger in 1990s when debt issuance was related to issuances of international commercial papers by the pharmaceutical company Pliva and the food manufacturer Podravka. 1990s have been marked with absence of longer maturity government bonds, and thus absence of a clear benchmark for pricing debt instruments of corporate or municipal borrowers. The exception have been big bonds for banks restructurings, reconstruction and development, gradual public debt repayments from old foreign exchange savings, debt repayments arising from takeover of corporate debt by the government and its swap to government ownership stake in firms. Fixed interest rates varied from 5-12,5\% with maturities from 
Figure 5: Stock market activity, 1997-2015

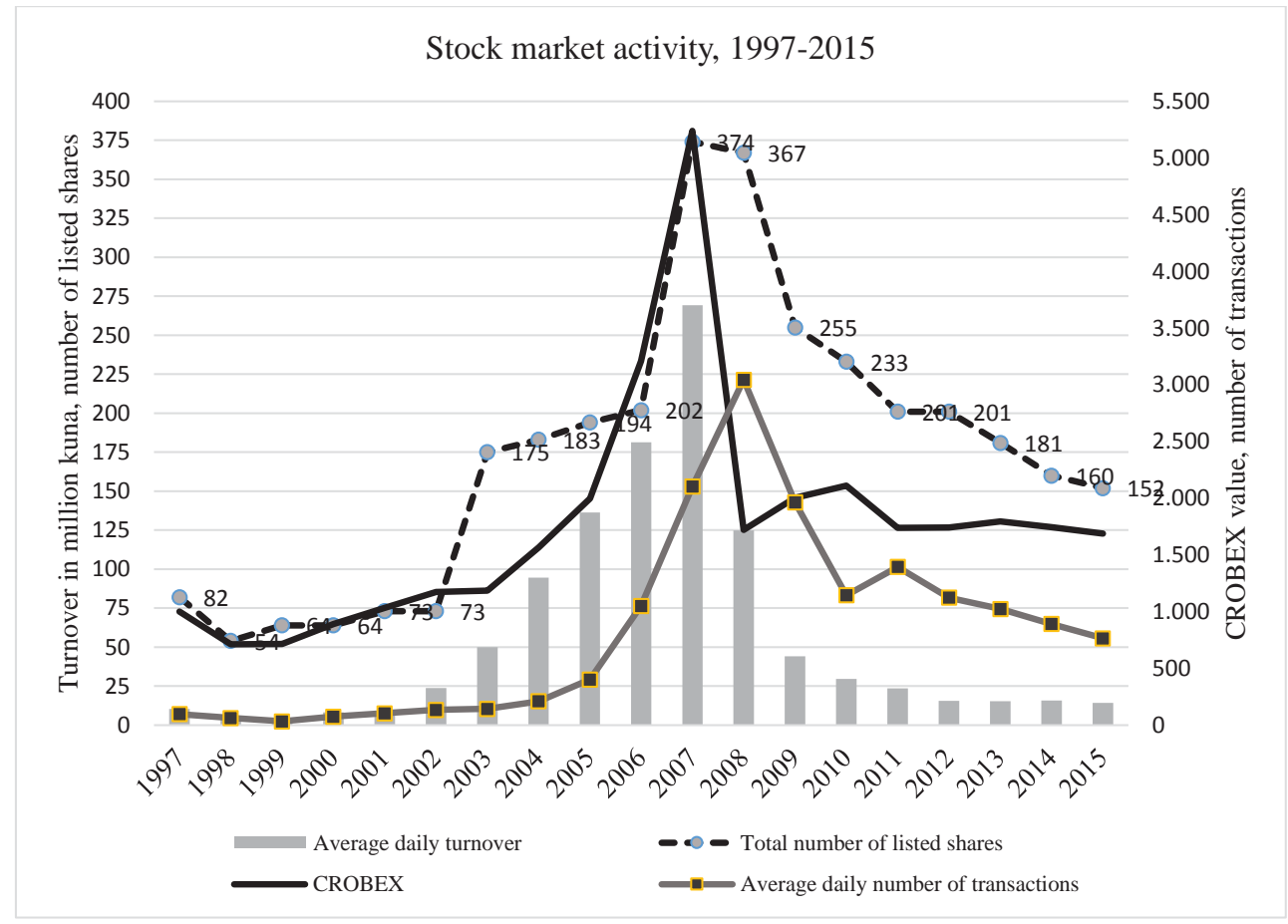

Source: Adapted from the ZSE statistical reports

5-15 years. The first euro-denominated Croatian bonds were issued in 1997 with 2 -year maturity and $12,5 \%$ semi-annual interest rate. The 300 million euro issue was equally split between domestic and international capital market. That year kuna was accepted by Euroclear system of international clearing and settlement. The first USD-denominated government bonds were issued in 1997 with five-year maturity and 7\% interest rate. Significant Treasury bill auctions started in 2000 with 2,5 billion kuna overall principal compared to 11,5 billion kuna principal arising from big bonds. Bonds of Croatian health insurance company and the State agency for deposit insurance and bank resolution were the first government-backed bonds issued in the domestic capital market maturing from 3-5 years, whose overall principal exceeded 4 billion kuna with interest rates from 8-8,5\% in 2001. The issuance of 400 million euro pure government bonds (converted to kuna) followed shortly and it was equally split between 3 and 7 year maturity and interest rate of 6,5\% and 6,875\%, respectively in 2001. First 650 million euro 10-year and 200 million euro 15-year kuna denominated (but fixed to euro) government bonds were issued in 2004 with interest rates of 5,5\% and 5,375\% p.a. In 2003, the first 5-year pure kuna bond and in 2003, the first 10-year pure-kuna bond were created, establishing a benchmark long-term 
yield curve in national currency. The government debt activity greatly outnumbered corporate debt issuance ever since.

Starting from 2012, the structured products issued by banks are offered on the Zagreb stock exchange, but they are targeted mostly to institutional investors.

\section{Investor Protection}

Investor protection has been guaranteed by the Company act, capital market regulation and stock exchange rules. Investor protection relies on transparency of companies in whose securities investors put their funds, rule of law regarding equal treatment of investors in designated classes of securities, exercise of voting rights and court protection in case of (potentially) harmful corporate actions towards minority investors. There have been three phases of investor protection in the Croatian capital market. The first phase lasted from 1990s to 2002, the second, transitory phase was in place from mid-2002 to the end of 2008, while the last, third phase began with the application of new Capital market act in 2009. Until 2002, only corporate issuers whose shares were listed in the top market quotation needed to report their financial results quarterly. Price manipulation and market abuse have been frequent without effective counter-measures. From mid-2002, quarterly financial reporting has been applied to all share issuers in top tier market quotation as well as in quotation of the companies that fulfilled the mandatory listing criteria. The issuers fulfilling capital requirement or minimum number of shareholders could choose between the listing on either Zagreb or Varaždin stock exchange at the time, and some of them even chose listing their shares on both exchanges. The Zagreb stock exchange and Varaždin stock exchange established a new quotation for the so called public joint stock companies, i.e. the quotation for mandatorily listed shares. Prospectus issuance rule became valid for all listed shares. From 2009 thereon, the quarterly reporting relies on all the companies whose shares are quoted on regulated market, consisting of three quotations - prime market, official market, and regular market. The law in detail prescribes the content of prospectus in case of securities offering to the general public. These documents are now much thicker and contain very detailed information on the issuer, the securities, investment risks and expected treatment of the investors by the issuer. In line with regular financial reporting, there are many other reporting obligations such as those on certain percentages change in voting rights / ownership stakes, corporate governance codes, general assembly voting rules and decisions, management board discussion and analysis, reports with anticipated business outlook and risks, and disclosure of other relevant information for investment decisions. The prescribed, to-be disclosed, information have been available to investors not only on the internet site of the Zagreb stock exchange, but also in the registry of the Croatian Financial Services Supervisory Agency (HANFA) and on the internet pages of the issuers. Looser rules apply to the issuers on the multilateral trading platform. 
The Zagreb stock exchange published its first corporate governance code in 2007, which was amended in 2010 and 2013. Corporate governance code for the listing companies united the capital market regulatory requirements with the company law and best practice corporate governance rules suggested by the OECD. Corporate governance code that has been mandatory since 2011 for publicly listed companies, has been primarily an administrative requirement fulfilment for most companies, especially those that do not have designated employees for communication with investors. The investor protection fund has been established by the new Capital market act guaranteeing the clients of institutional investors a refund of up to 150.000 kuna in case of claims against troubled institutional investors that dispose of clients' funds or lead their portfolios. However, there is no protection of small investors who lose their funds as a result of decisions of the general assemblies targeted to minority shareholders squeeze-outs. A typical investor protection rule is the pre-emption right to subscribe new corporate shares of the issuer. However, this right can and it is often taken away from the minority shareholders in practice if at least $75 \%$ votes in the general assembly are given to the decision to exclude minority shareholders from further capital increase. This especially happens from the beginning of the stock market slump in 2008. Although the data on free float market capitalisation are available from 2013, the data on the top ten shareholders in most liquid companies on the Zagreb stock exchange reveal striking ownership concentration in corporate issuers. For example, the free float of oil and gas company is after discarding the first 10 shareholders only about $1,5 \%$, while the free float of Croatian telecom is slightly above $23 \%$. Free float of other most liquid companies is typically less than $25 \%$ and in cases of companies with large market capitalisation even less than $15 \%$, warning that minority investors cannot decide on any corporate actions on their own. The concentrated majority ownership in most listed companies enabled major investor(s) to easily exclude minority shareholders from capital increase and dilute their ownership stake in the companies. Similarly, the takeover / delisting rule allows the acquirer to take over securities from investors at the price that is not lower than three month average price achieved on the stock market. Although this rule favours investors at the time of stock market rise, in case of market downturn, this rule may enable takeover by majority owner at the price that has nothing in common with the fundamental value of the company. The investors that refuse to sell their shares at the price offered and do not appeal to the court within one month after the call for shares repurchase, have scarce possibilities regarding the later determination of the shares price if they decide to sell their shares to the issuing company, unless they are in position to pay the auditor / court expert for determining the fair value of the company and their shares. Many well-known companies have delisted their shares from the onset of the financial crisis. Among others, there are: hotel companies Istraturist and Laguna Novigrad, retailer Konzum, Erste bank, etc. Some issuers, however, opted for exit from the regulated market by temporary listing their shares on the multilateral trad- 
ing platform before final delisting such as coffee manufacturer Franck and shipping company Tankerska plovidba. The majority of delisted companies have been SMEs forced to admission to the market by the mandatory listing rule of 2002 and that have solid reputation and thus no reason to be included in trading for advertising reasons. Thus, a positive side of mass delistings is a self-cleaning process among listed companies to only the companies that want to be listed on the market. A major drawback of the system is that in closely held domestic companies with thin free float, despite a significant number of financial and non-financial information on the issuer available to all stakeholders, a small investor is not treated as a shareholder but as a stakeholder, who cannot foresee further corporate actions regarding the dilution of minority shareholders stake (squeeze-out or delisting), which makes investing in shares very risky. For a comparison of investor protection in the region see Tipurić et al., 2013.

The taxation regime is one of the significant obstacles to capital market development. No cash flows earned on the capital market have been taxed until 2000. Heavier taxation on capital market earnings is related to the taxation policy adopted by the left-wing political party that introduced withholding tax on dividends and taxation of gains realised from options on shares purchase in 2001. The former have been taxed ever since, while the latter have not been taxed between 2005 and early 2012. However, in spite of thin liquidity, the left-wing political block introduced full capital gain taxation realised by natural persons as of the beginning of 2016, causing further decrease in small investor presence on the market.

The actions of Zagreb stock exchange promoting the role of the stock exchange stay as sole attempts to recover the confidence of small investors into the market that is significantly ruined by the majority investor prone regulation. Further attempts to join the trading platform of Zagreb stock exchange with the trading platform of other regional stock exchanges known as the SEE link that is established in the first quarter of 2016 also cannot alone recover the small investor confidence and boost market liquidity. Due to thin market, prevailing institutional investor influence on securities prices, and unclear regulatory policy towards minority investor protection and changing taxation regime, small investor activities remain negligible, confirming the third hypothesis.

\section{Conclusion}

The developing path of the Croatian capital market can be divided into three phases. The first phase was dominated by privatisation flows, early market rules, first institutional investors, and voluntary listings of major domestic companies. The second phase is characterised by the mandatory share listing rule, vivid activity on two stock exchanges, emergence of the investment and pension funds, and increase in government debt issuance on domestic market. The third phase is a modern capital market 
in a regulatory sense, adjusted to the EU acquis, but still with absence of minority shareholders rights protection, thin and illiquid.

The regulatory and institutional market development has not enlivened the primary role of the stock exchange as an intermediary for corporate securities issuance and capital collection. It has rather supported already strong ownership concentration in domestic companies. The market serves as an almost exclusive platform for institutional investor actions. Small investors have been forced to pull back from the market unless willing to exercise pure buy and hold policy in corporate securities. The number of listed companies has been gradually decreasing from 2009, unless the companies voluntarily want to have a channel for relatively low-cost advertising and other indirect gains of transparent policy towards their stakeholders.

In a nutshell, despite regulatory advances, small free float, government divestitures in major companies, government debt issuances, institutional investor creation and market influence, undefined government policy towards the capital market role in general and small investors in particular remain the main features of the Croatian capital market development in the last 20 years.

\section{REFERENCES}

Anić Antić, P., Ramljak, B. (2010). Korelacija tržišne cijene dionica i uspješnosti poslovanja poduzeća koja kotiraju na tržištu kapitala Republike Hrvatske: Posljedice za proces odlučivanja. Ekonomski pregled. 61 (11), str. 666-682.

Benić, V., Franić, I. (2008). Komparativna analiza likvidnosti tržišta kapitala Hrvatske i zemalja regije. Financijska teorija i praksa. 32 (4), str. 481-502.

Buljat, M., Ivanović, Z., Baresa, S. (2015). Analysis of the Capital Market in Croatia. UTMS Journal of Economics. 6 (2), pp. 223-232.

Čulinović Herc, E. (2009). Povreda obveze objave podataka na tržištu kapitala i sporovi ulagatelja (dioničara) protiv uvrštenih društava. Zbornik Pravnog fakulteta Sveučilišsta u Rijeci, 30 (1), str. 135-170.

Čulinović Herc, E., Zubović, A. (2013). Open issues of the squeeze out right in Croatian and the EU court practices. In Bodiroga, V. et al. (Eds.), Legal Culture in Transition - Supranational and International Law Before National Courts (pp.159-180). Berlin: Logos Verlag.

Gambacorta, L., Yang J. \& Tsatsaronis, K. (2014) . Financial structure and growth. BIS Quarterly Review. March, pp. 21-35.

Grubišić Šeba, M. (2013). Troškovi izdavatelja vrijednosnih papira na hrvatskom tržištu kapitala. Ekonomski pregled. 64 (3), str. 213-240.

Grubišić Šeba, M. (2013). Financing policies of Croatian publicly listed firms. UTMS Journal of Economics. 4 (2), pp.127-141.

Grubišić Šeba, M. (2015). Mandatory shares listing effect on further capital raising in the Croatian capital market from 2002-2010. Economic research - Ekonomska istraživanja. 28 (1), pp. 1079-1095.

Grubišić Šeba, M., Orsag, S. (2015). Corporate motives for public shares offering during the financial crisis. UTMS Journal of Economics. 6 (1), pp. 99-114.

Kogut, B., Spicer A. (2002). Capital market development and mass privatization are logical contradictions: Lessons from Russia and the Czech Republic. Industrial and Corporate Change. 11 (1), pp. 1-37. 
La Porta, R., Lopez-de-Silanes F., Shleifer, A., Vishny, R. (2000). Investor protection and corporate governance. Journal of Financial Economics. 58, pp. 3-27.

Miloš Sprčić, D., Wilson, I. (2007). The Development of the Corporate Bond Market in Croatia. EuroMed Journal of Business. 2 (1), pp. 74-86.

Minović J. Z. (2012). Liquidity of the Croatian stock market: An empirical analysis. Economic research-Ekonomska istraživanja. 25 (3), pp. 776-802.

OECD (2003). White paper on corporate governance in South Eastern Europe. https://www.oecd.org/ daf/ca/corporategovernanceprinciples/20490351.pdf.

Prohaska, Z., Olgić Draženović, B. (2010). Development of government bonds market in Croatia., In Proceedings from An Enterprise Odyssey: From Crisis to Prosperity - Challenges for Government and Business (pp. 833-841). Zagreb: Faculty of Economics and Business. https://bib.irb.hr/ datoteka/461041.62ProhaskaOlgicDrazenovic.pdf.

Sajter, D., Čorić T. (2009). (I)rationality of Investors on Croatian Stock Market - Explaining the Impact of American Indices on Croatian Stock Index. Zagreb: Faculty of Economics and Business Working Paper Series, No. 09-01.

Tipurić, D., Trivun V., Mrgud M. \& Šukleva, M. (2013). Protection of minority shareholders in B\&H, Croatia, Macedonia, Montenegro and Serbia. Montenegrian Journal of Economics. 9 (2), Special issue, pp. 55-69.

Orsag, S. (2011). Oporezivanje kapitalnih dobitaka. Ekonomija/Economics, 18 (1), str. 73-98.

Štimac, D. (2011). Tržište javnog duga u Hrvatskoj: pogled institucionalnih investitora. U Zborniku radova s konferencije: Hrvatski javni dug: upravljanje i izazovi razvoja tržišta (str. 81-96). Zagreb: Institut za javne financije. 